\title{
Aproximações e distanciamentos: novos e velhos trecheiros
}

\author{
Sandra Büll ${ }^{1}$ e Márcia Hespanhol Bernardo² \\ Pontifícia Universidade Católica de Campinas (Campinas, SP)
}

O presente artigo foi escrito a partir de uma pesquisa de mestrado e objetiva discutir a ida às ruas como um processo gradativo e contínuo, para além da ideia simplista do viver nas ruas como produto de uma escolha de sujeitos que não aceitam trabalhar. $\mathrm{O}$ estudo foi desenvolvido ao longo de seis meses, por meio de etnografia. Foram contatadas cerca de 100 pessoas em situação de rua, os chamados "trecheiros", que se mantêm em mobilidade constante, de cidade em cidade, ou de "trecho em trecho", desenvolvendo atividades laborais desqualificadas, temporárias e/ou sazonais como forma de subsistência. Os dados construídos foram analisados à luz da Psicologia Social. Serão contrapostas aqui duas entrevistas realizadas com trecheiros: uma com um homem de 36 anos, entrevistado em uma praça de um município do interior paulista, artesão, que se identifica como trabalhador, recusa-se a fazer uso de políticas de assistência pública e atribui sua ida às ruas a uma escolha pessoal, afirmando-se livre e feliz. O segundo, de 60 anos, identifica-se como trabalhador e alcoólico, atualmente interno em uma instituição de atendimento a pessoas em situação de rua, compara-se a seus irmãos que possuem vida financeira mais segura e identifica a rua como um local de liberdade e privações.

Palavras-chave: Pessoas em situação de rua, Trecheiros, Trabalho, Psicologia social.

Similarities and differences: old and new roamers

The present article was written from a master's research and aims to discuss going to the streets as a continuous and gradual process, beyond the simplistic idea of living in the streets as a product of someone's choice of not accepting to work. The study was developed in six months by means of Ethnography. 100 people living on the streets, in constant mobility from town to town, developing disqualified work activities, temporary and/or seasonal as a way of subsisting were interviewed, the so called "trecheiros". The data was analyzed using Social Psychology. Two interviews with the "trecheiros" will be counterposed: a 36 year old man, interviewed in a city in the state of São Paulo at a park, who is a craftsman and identifies himself as a worker, refuses to use the public assistance and attributes his living in the streets as a choice, he feels happy in the streets. The second: a 60 year old man who identifies himself as a worker and an alcoholic who attends an institution that assists street population. He compares himself to his brothers who are financially more stable and identifies the streets as a place of freedom and deprivation.

Keywords: Street population, Roamers, Work, Social psychology.

\section{Introdução} presença de pessoas em situação de rua é um fenômeno antigo, que remonta à
populações mituiçáo das primeiras cidades (Santos, 2004). Podem ser encontradas fortes alusões a
relacionam tal situação ao processo de urbanização e de concentração de riquezas ocorrido
durante a Revolução Industrial na Europa (Bresciani, 1982; Himmelfarb, 1998; Hobsbawm,
1982).

O tratamento dispensado a essa categoria populacional tanto na Inglaterra quanto na França variou, ao longo da história, da assistência relegada à caridade cristã feita por fiéis

1 Mestre em Psicologia pela Pontifícia Universidade Católica de Campinas.

2 Docente do Programa de Pós-Graduação Stricto Sensu de Psicologia da Pontifícia Universidade Católica de Campinas. 
sensibilizados até a coerção ao trabalho como meio de punição, educação e tentativa de inserção social (Bresciani, 1982; Hobsbawm, 1982).

No Brasil, as primeiras alusões a pessoas em situação de rua referem-se a negros antes escravos, agora recém libertos, que, por não encontrarem atividades remuneradas que lhes garantissem a sobrevivência, foram para as cidades e permaneceram habitando as ruas e demais logradouros públicos urbanos. Aos negros somaram-se ainda várias levas de imigrantes europeus não alocados no trabalho no campo (Santos, 2004).

Hoje, de acordo com números apontados pelo primeiro Censo Nacional por amostragem, publicado em 2008 e realizado pelo Ministério do Desenvolvimento Social e Combate à Fome, estima-se um total de 44.875 pessoas em situação de rua, das quais 11,9\% seriam trecheiros, ou seja, pessoas que se mantêm em circularidade constante. Tais números foram obtidos a partir de uma contagem realizada em 48 municípios com 300.000 ou mais habitantes, 23 capitais de estado e o Distrito Federal, perfazendo um total de 71 municípios (Brasil, 2008).

De acordo com a literatura científica e também com os dados apontados pelo Censo de 2008, pode-se perceber que a expressão "pessoas em situação de rua" abarca inúmeros segmentos populacionais bastante heterogêneos, entre eles o objeto do presente artigo, os trecheiros, que serão aqui tomados como:

...desvinculados da família e do trabalho, buscam a sobrevivência nos caminhos do país. Caminham de cidade em cidade, de vila em vila, de campo em campo. Raramente retornam à família, por isso seu destino mais fácil é tornarem-se moradores de rua (Bastos, Toseli, Aquino Júnior \& Bove, 2003, p. 20).

Acrescentam-se, ainda, as afirmações de Brognoli (1996) de que, apesar de a busca pelo trabalho ser uma referência constante entre os trecheiros e mesmo uma marca característica desses, não seria o trabalho que determinaria o trajeto a ser percorrido. Segundo o autor, o trabalho esporádico surgiria como suporte material à manutenção da errância e, assim, a necessidade de afirmar-se como trabalhador representaria muito mais uma forma de distinção moral do que uma busca real. Desse modo, os inúmeros "bicos" manteriam o constante caminhar, mas não seria a oportunidade de trabalho em outras cidades que os forçaria ao deslocamento.

Frangella (2004) corrobora as afirmações de Brognoli (1996) ao conceituar o trecheiro como um trabalhador em busca de oportunidades de emprego, que vaga de "trecho em trecho", ressaltando que, muitas vezes, esse trabalhador guarda do trabalho apenas o discurso, terminando por tornar a circularidade constante um fim em si.

O presente artigo busca discutir a ida para as ruas como um processo gradativo e contínuo não adequadamente contemplado por concepções que partem unicamente de referenciais econômicos de análise ou ainda da visão simplista que situa as pessoas em situação de rua como sujeitos fora do mundo do trabalho por decisão própria ou devido à dependência de álcool e drogas. Busca-se, ainda, evidenciar a importância da categoria trabalho como estruturante da subjetividade contemporânea, apontando que a atividade profissional pregressa é utilizada como forma de dizer de si, de expressar qualidades e defeitos pessoais e narrar o lugar de pertencimento social - seja no seio familiar, seja em um contexto social mais amplo -, ainda que a atividade propriamente dita já não seja realizada há tempos. 


\section{Método: o percurso no trecho}

A pesquisa que deu origem a este artigo foi desenvolvida por meio de etnografia, que tem como pressuposto a necessidade de imersão do pesquisador no universo que pretende estudar, para, assim, poder compreendê-lo a partir de sua complexidade. Nessa metodologia, o pesquisador tem um papel ativo em uma situação natural, reconhecendo-se como participante da pesquisa (Hammersley \& Atkinson, 1994; Chizzotti, 2006).

As contribuições trazidas por Da Matta (1978), ao distinguir os chamados etnógrafos "nativos" - que estudam sua própria sociedade - dos etnógrafos "internacionais" - que estudam sociedades distintas da sua - caracterizam o esforço intentado no presente trabalho: transformar o familiar em exótico e, por meio do olhar de estranhamento, desnaturalizar os múltiplos processos históricos e sociais envolvidos na ida e permanências de pessoas no "trecho".

Outro aspecto metodológico a ser destacado é a natureza da população escolhida para a investigação, que, como lembram Hammersley e Atkinson (1994), é fundamental para o desenvolvimento de uma pesquisa etnográfica. $O$ fato de a não fixação em um mesmo logradouro urbano ser o que caracteriza a população focalizada neste estudo apresentou-se como um desafio para o trabalho de campo. Não era possível à pesquisadora tornar-se "trecheira". Assim, para contemplar a maior imersão possível no campo, optou-se pela permanência durante cerca de quatro horas, três vezes por semana, nas praças e ruas próximas ao Terminal Rodoviário de um município do interior paulista, que se configura como um local de passagem para essa população. Foram ainda incluídas visitas a uma instituição municipal que atende pessoas em situação de rua. Este trabalho foi realizado entre 2009 e 2010 e teve duração de seis meses. No total, foram contatados cerca de 100 trecheiros, dentre os quais dois terão suas histórias de vida apresentadas e analisadas em profundidade neste artigo.

Os depoimentos foram obtidos por meio de entrevista informal, que caracteriza o trabalho etnográfico. De acordo com Hammersley e Atkinson (1994):

A principal diferença entre as entrevistas realizadas por etnógrafos e as entrevistas com questionários não é, como frequentemente se sugere, que umas sejam "desestruturadas" e as outras "estruturadas"... A diferença fundamental está em que umas são entrevistas reflexivas e outras são padronizadas. Os etnógrafos não decidem de antemão as questões que querem formular, ainda que costumem entrar na entrevista com uma lista de temas dos quais querem falar. Os etnógrafos tampouco se restringem a uma única maneira de indagar. Em diferentes entrevistas, ou em diferentes momentos de uma mesma entrevista, a aproximação a um tema pode ser direta ou indireta, dependendo da questão que é buscada (Hammersley \& Atkinson, 1994, p. 129).

Uma das entrevistas analisadas aqui foi realizada em uma praça, tendo sido anotada em papel no decorrer do seu andamento por solicitação do entrevistado, que fez questão de, ao final, ler o que foi escrito. A outra foi realizada na instituição municipal de acolhimento à população de rua, tendo sido gravada em áudio e posteriormente transcrita.

A entrevista realizada na instituição não é considerada como "fora do trecho", tanto por seu importante conteúdo quanto porque se considerou a passagem pela instituição como uma das muitas estratégias que perpetuam o "estar na rua". No decorrer da sua fala, o entrevistado declarou inúmeras vezes ter feito uso dos serviços oferecidos sem que isso alterasse o processo de retorno ao trecho.

Essas duas entrevistas foram escolhidas devido às proximidades e aos distanciamentos verificados entre as histórias dos entrevistados: um era jovem, vivia no trecho no momento da 
entrevista, sentia-se livre, afirmava não ter problemas com álcool e/ou outras drogas. O outro, mais velho, encontrava-se na instituição de acolhimento no momento da entrevista, dizia-se culpado pelo tempo passado na rua e afirmava-se como alcoólico. Conforme se buscará mostrar em seguida, esse aparente antagonismo indica a complexidade que envolve a ida para o trecho e a permanência nele.

O conteúdo das falas dos dois trecheiros foi analisado considerando o contexto em que os sujeitos estão inseridos e buscando interpretar os sentidos subjacentes a elas (Geertz, 1989).

\section{O velho trecheiro: liberdade e aprisionamento}

Erasmo, apelido pelo qual o trecheiro Alberto, 60 anos, é conhecido, estava então na instituição que abriga pessoas em situação de rua pela quarta vez, havia cerca de um mês e meio, após permanecer por três meses no trecho. Iniciou sua narrativa falando da perda de sua mãe e da vida nas ruas:

O que complicou mais a minha vida foi, uma, que minha mãe morreu e, outra, que complicou mais, foi que eu conheci os caras da rua. Eu não sabia pedir nem um cigarro pra ninguém e fui aprendendo, porque, depois nós (ele e mais oito colegas da rua) fomos morar num gramado, embaixo das árvores, e cada um tinha uma namorada.

Volta algum tempo em sua história, falando da fase antes da rua, do trabalho árduo. Passa a contrapor a vida nas ruas e sua vida anterior, como a tentar, por meio do contraste, dar sentido a uma e outra, característica narrativa por ele mantida até o final de seu relato.

...naquele tempo eu tinha meu trabalho, tinha meu dinheiro, só num lugar na M. trabalhei uns quinze anos, empregado, mas bem dizer por conta, porque não era registrado. Eu trabalhei em muitos lugares, firma, tive oficina minha, eu mais um outro rapaz que tomava conta. Mas depois que bloqueou aquele dinheiro (refere-se ao chamado plano Collor que entrou em vigor em $1990 \mathrm{e}$ bloqueou as poupanças de todos os brasileiros), eu tive que fechar. Nós, como pagava aluguel... Meu pai tomava conta, então tinha um outro rapaz que era, ele era encanador, eu como encanador, meu irmão era ajudante, nós tinha mais uns quatro ajudantes. Mas nós não se ligava como patrão não, onde a gente almoçava todo mundo almoçava também.

É-lhe impossível falar de si sem recorrer a seu lugar de trabalhador. Como proprietário de uma pequena oficina faz questão de se colocar como igual aos demais funcionários, por meio da comunhão da mesa e da comida como forma de negar o papel de patrão. Essa ênfase dada por Erasmo ao trabalho quando fala de si parece corroborar a afirmação de Jacques (2006), segundo a qual a importância do papel social de trabalhador na construção da subjetividade contemporânea é de tal ordem que, "ao tentar dizer 'quem é', a própria linguagem induz a dizer 'o que alguém é', reservando um lugar de destaque ao papel de trabalhador" (p. 22). O trabalho serve como definidor do lugar social ocupado pelo trabalhador; mais do que isso, é, sobretudo, pela participação no mundo do trabalho que se dá a inserção social contemporânea.

Além de iniciar sua fala ressaltando seu lugar de trabalhador, pode-se também vislumbrar na fala de Erasmo como seu papel social de responsabilidade na família é apresentado em forte associação ao trabalho árduo por ele desempenhado: criança-homemarrimo-de-família, irmão-mais-velho-pai, papéis intimamente associados e que lhe impõem renúncias e responsabilidades: 
Se fossem todos vivos, éramos em 18 irmãos, eu sou o mais velho. Como nós éramos em muitos irmãos, eu precisei trabalhar logo, ajudar meu pai, fiz até o terceiro ano primário só. Daí eu comecei a trabalhar, foi numa agência de carro, ficar limpando carro, tomar conta, nem lembro o que ganhava, mas era uma merreca que olha... Comecei a trabalhar com uns 13 anos, trabalhava todo dia e depois quando voltava pra casa tinha o Mobral. Aí entrei no Mobral, mas eu não aguentei a barra, porque eu tinha que chegar do trabalho e ir pra escola. Eu trabalhava na AR e morava na M. (dois bairros distantes entre si). Tinha dia que não tinha dinheiro nem pra pegar condução e tinha que ir a pé e, às vezes, não tinha nem a marmita, era muita criança e... todo ano nós tinha um irmãozinho novo. E agora o único que ficou na pior fui eu, e foi por culpa minha mesmo.

Aparentemente buscando recursos para compreender a passagem de sua vida de trabalhador e arrimo de família a trecheiro, passa a falar da vida nas ruas. Ensaia uma explicação para essa passagem e, ainda que de modo incipiente, arrisca uma distinção entre os trecheiros - andarilhos - e aqueles que permanecem em um mesmo município - conhecidos na linguagem das ruas, apropriada também pela literatura científica, como pardais. $\mathrm{O}$ entrevistado passa a percorrer seu caminho de apropriação do código de vida e sobrevivência nas ruas:

Aquele tempo tinha muito trecheiro, tinha muito trecheiro pra rua, demais. O trecheiro, mesmo, ele não fica na cidade, ele não fica dois, três dias, some, vai pra outra. Agora o morador de rua, eles falam pardal, é pardal porque não sai da cidade. Quando é 14h30, 15 horas é que vai pedir comida, porque essa hora (por volta de 12 horas, momento em que a entrevista é realizada), os restaurantes é pros fregueses, né, quando é umas 15 horas já não tem movimento... Sempre tem uma mochila, ali tem birita, uma roupa, uma coberta (refere-se aos trecheiros). Eu, há uns 30 anos atrás, não chega a 30, não sabia pedir, aí conheci a moça, ela perguntou se eu morava na rua e eu falei que ia ficar lá com eles e ela disse: "com essa sua roupa aí não dá". Eu perguntei o porquê e ela disse: "Olha essa sua roupa aí, seu sapato como que é, como que você vai pedir uma comida?... Você tá vendo todo mundo aí, ó, tudo simples, de chinelo de dedo, uma bermuda meio zuada". Eu fui pedir dinheiro com essa namorada numa casa, mas eu tinha vergonha e ela disse: "Ou você pede, ou rouba ou morre de fome, uma rua tem muitas casas, se dez não dá, uma outra dá". Aí um trecheiro que estava com a gente disse: "você sabe o que tem que fazer? Beber, beber pra pedir". E nós comprava garrafa, gorotinho (vasilhame de plástico com volume de 500 $\mathrm{ml}$ de cachaça), e então nós tomava, tomava, já de manhã mesmo.

Ainda que fosse um trabalhador pobre e braçal, acostumado a dificuldades e privações, o pedir não the era familiar, sua rede de amparo social circunscrevia-se à família. Aliás, foi nele que os pais encontraram suporte à criação dos numerosos filhos. Estava acostumado a não ter, mas não a pedir.

Erasmo não decidiu permanecer nas ruas, não o fez em uma passagem brusca, imediata, de uma condição a outra; começou, sim, passando algum tempo nas ruas para não ficar em casa com os irmãos com os quais brigava sempre. Conheceu pessoas, fez amizades e o tempo de permanência fora de casa foi pouco a pouco aumentando. Trabalhava em São Paulo como encanador e, quando ia para o interior, ficava nas ruas e praças.

Afirma que, na época, usava cabelos compridos e "aquelas roupas meia gozada (ri, referindo-se às calças boca de sino), nos modos que eu usava em São Paulo, eu usava aqui". Parece marcar, por meio da descrição pormenorizada de seus trajes e costumes, que os códigos de sobrevivência nas ruas não lhe eram familiares e foram aprendidos aos poucos.

Erasmo, interno na instituição, mostra-se extremamente vaidoso: apresenta-se com os cabelos e o volumoso bigode impecáveis. Nas mãos, muitos anéis e pulseiras. Fala com saudades dos cabelos antes compridos, que chegavam até a cintura. Tinha seu trabalho e podia cuidar deles com cremes. Continua ele, referindo-se à condição de trecheiro: 
Isso aí é uma sina. Isso aí até eu não entendo... A minha vida nem eu não entendo. Trabalhar eu sempre trabalhei, se eu fico aqui dentro só, eu fico encabulado. Não sei se você reparou que está tudo ali carpido a rua. Eu carpo tudo!

A concepção da vida no trecho como "uma sina" pode também ser encontrada no relato apresentado por Brognoli (1996), no qual um trecheiro afirma que foi para a rua por conta de um feitiço lançado por sua mãe que depositara nele um "Exu andarilho" e fadara-o à errância. Em última análise, parece dizer de um sentimento de quem não sabe ao certo como se deu seu processo de "rualização" e termina por encontrar no sobrenatural, no destino, em um, talvez, propósito divino, elementos que confiram coerência à sua trajetória de vida.

Paugam (2003) fornece elementos para a compreensão da necessidade de Erasmo de se manter ocupado ao revelar que a não inserção do mercado de trabalho fere diretamente a honra dos sujeitos pertencentes às classes mais pobres. O não trabalho é, então, experimentado como humilhação e a dependência da assistência. É como um selo de formalização da incapacidade de se manter por si. $\mathrm{O}$ autor atribui a isso o apego ao trabalho constantemente identificado nessas populações.

Por outro lado, Erasmo apresenta uma série de justificativas para a culpa por sua situação. Conta de sua juventude e afirma-se como trabalhador, mas sua relação com o trabalho não é a de busca de acumulação ou estabilidade, mas de um trabalho que lhe permita dinheiro suficiente para as necessidades imediatas, sejam elas o alimento dos irmãos, os cadernos da sobrinha, sejam sua pinga no final do dia. Assim, gastava muito rapidamente todo o dinheiro recebido.

Mais tarde, ele e seus irmãos seguiram caminhos distintos. Erasmo se compara a eles, culpando-se por não ter atingido as mesmas conquistas materiais:

Eu gostava de beber bastante. Trabalhava, só que quando chegava fim de semana, eu pegava dinheiro. Os outros guardavam e eu não, eu ia pra praia. Eu gostava de ir pra praia numa sextafeira e voltava na segunda-feira. Eu sou o culpado de tudo o que aconteceu, porque não tem um dos meus irmãos que não tem casa, carro. Minha irmã tem um bar, tem quatro casas de aluguel.

Afirma-se como alcoólico e atribui a si e à vontade de beber a responsabilidade pelos atuais problemas. Em seguida, revela que sua mãe sempre bebeu, vindo a falecer de "derrame cerebral".

Seligmann-Silva (1994) afirma que boa parte dos casos de alcoolismo entre trabalhadores estão ligados à necessidade de "relaxar" ou, também, a "uma busca de satisfação compensatória a frustrações profissionais ou à falta de prazeres acessíveis, inclusive de relacionamentos afetivos ou de oportunidades de lazer significativo" (p. 183). A autora pontua, desse modo, que o alcoolismo pode se configurar como uma anestesia da dor psíquica com vistas a uma não consciência, para poder manter a situação então vivida.

De volta à narrativa, Erasmo retoma sua juventude e relata com orgulho e prazer sua primeira viagem no trecho, mostrando que a vida nas ruas também lhe proporcionava prazer e sensação de liberdade.

Fui pro Rio de Janeiro. Eu pedi a conta da firma, trabalhava numa firma de válvula hidra de banheiro. Ele (um amigo) pediu também. Ele era motorista. Daí nós fomos pro Rio de Janeiro. Cheguei no Rio de Janeiro de paletó. Mas eu jamais pensava em entrar no trecho. Tentar no Rio de Janeiro (refere-se a conseguir trabalho), porque o Rio de Janeiro sempre teve nome, eu era muito novinho ainda. Aí nós com o dinheiro, ao invés de nós ir procurar trabalho, começamos ir pra Copacabana, tomar P. S. G. (marcas de bebidas destiladas), peixe, cheios de querer, todo dia na praia. Passou quatro dias, acabou o dinheiro, daí a fome apertou e eu não sabia pedir. Cada 
coisa que a gente chegava na praia e via - porque aqueles turistas sempre jogam coisas - a gente comia. O que acontece? Falei: "Mané, como a gente vai fazer na vida? A fome, a gente comendo essas coisas aí, tudo errado". Aí nós viemos a pé, doze dias, quase que eu morri de tanta fome. Só pra subir a serra demoramos três dias. Cada vez que eu olhava pra trás, eu via o Cristo ainda (a estátua do Cristo Redentor) e eu digo: "Nós vamos morrer!" e aqueles carros passando (ri), maior barato!

Rememora sua juventude contrapondo dor e prazer. Em seu discurso parece existir um quê de fala institucional, que ele incorpora ao se referir a si como irresponsável, ao se dar em voz alta o conselho que lhe daria alguém que o chama a precaver-se para o futuro, aconselhando-o a procurar emprego e guardar dinheiro para sua subsistência no Rio de Janeiro. O menino Erasmo se ri dos conselhos e conta as dificuldades com prazer e ares de aventura.

Eu falava: "Mané, vamos olhar pra trás? Vê se você vê o Cristo, porque a serra era enorme". E ele falava: "Vê você". Porque ele era bem escuro (negro) e ele estava amarelo, vermelho, azul. Eu não tinha cor mais... tinha fome. A gente olhava pros carros, parecia que os carros estavam perto da gente e o carro estava lá na casa do chapéu, e aquela tontura. Se bem que água a gente achava bastante, porque a água sustenta, no morro sempre tem água, mas foi um sofrimento. Depois nós chegamos em Aparecida do Norte (cidade do interior paulista). Era tão fácil pedir uma comida lá. Então "vai você", "não, vai você", "não, vai você", "então não vai ninguém, vamos embora pra casa logo!”. Daí chegamos na estrada, só que tinha bastante aquelas barracas de madeira que vende fruta e o cara viu nós pegando fruta lá do chão e falou: "Vem aqui, por que você pegou fruta do chão, está com fome?" Eu digo: "Eu estou. Eu sou de São Paulo, mas não tenho coragem de pedir". Aí ele pegou um saco, botou um monte de fruta, aí segurou a barra um pouco. Só que eu estava bem amarelo já, tudo zuado (ri com prazer e os olhos brilhando), e vamos comendo. Só que depois melhorou porque daí, a cada um quilômetro, tinham as barraquinhas.

O trecheiro conta que, naquele tempo, podia sair de um trabalho e entrar em outro, pois a experiência prática lhe garantia a qualificação necessária para conseguir emprego com certa facilidade. Se não gostasse do novo emprego, esperava receber e não voltava nem para dar satisfações, o que é evidenciado na continuação de sua narrativa:

Quando passou um dia, dois, eu fui e já arrumei um trabalho, rapidinho. Eu trabalhei em metalúrgica, sapateiro. Eu sempre trabalhei como ajudante, mas, como eu ficava meio encabulado, eu queria aprender. Pranchador, depois trabalhei em fábrica de fio, mas sempre pouco tempo em qualquer lugar, porque trabalhava um pouquinho e, depois, faltava. Trabalhava num dia e faltava no outro. (Se) não mandavam embora, de segunda-feira eu não ia. Três, quatro meses e mandavam embora. Não ia porque eu bebia... chegava na segunda-feira não tinha aquele ânimo.

Em outra passagem, fala da grande mobilidade de emprego em emprego, mostrando como, no contexto da época, um trabalhador experiente podia ter certo poder de barganha:

Com a minha idade e já trabalhei em tanto lugar, teve firma que trabalhei um mês, teve firma que trabalhei dois dias, teve firma que trabalhei uma semana, porque eu bebia que eu saía dali e, no outro dia, aquela grana que eu pegava de pedir a conta eu já gastava porque sabia que no outro dia ganhava mais. (...) (No dia do pagamento) eu, como outros, pegava aquele dinheiro na hora do almoço e não voltava mais, não. E depois ia no outro dia trabalhar. Era legal porque eu estava com grana, ia beber cerveja.

É possível identificar prazer em seu impulso em abandonar o trabalho que não the agradava mais e sair para se divertir. Entretanto, agora rememora externando sentimentos de inferioridade em relação a seus irmãos capazes de se enquadrar e se manterem em trabalhos que lhes possibilitaram conseguir bens materiais. 
Mas, se olha para trás com arrependimento, atribuindo à bebida a responsabilidade por sua constante mudança de trabalho, também fala das características negativas do trabalho e revela que só conseguia ficar em um mesmo emprego enquanto aprendia algo. Enquanto estava aprendendo, mantinha-se curioso; depois, o tédio se instalava e vinham as faltas e a bebida. Deve-se lembrar de que essa fase da vida de Erasmo corresponde às décadas de 1960/70, auge do modelo de organização do trabalho taylorista-fordista no setor industrial brasileiro. Assim, sua fala parece indicar uma fuga à possibilidade de se transformar em "um instrumento no processo produtivo" (Braverman, 1987, p. 151), uma extensão da máquina.

Apesar da oscilação entre arrependimento e orgulho, a narrativa de Erasmo indica também um tipo de resistência ao sofrimento inscrito nesse processo de trabalho, que foi descrito de forma pormenorizada e ímpar por Simone Weil (Bosi, 1996). No entanto, sua resistência não se dá em um movimento interno no local de trabalho, mas por meio do afastamento sempre que possível.

Depois de relatar sua história, na qual descreve com riqueza de detalhes suas várias funções, como aprendeu, em que cidade as realizou, contou ter sido chamado recentemente para trabalhar em uma empresa, mas, como estava no trecho, não pôde ser localizado para comparecer à vaga. Quando indagado sobre seus sentimentos em relação a isso, demora a responder e diz: "Bom, eu não sabia quando iam me chamar, senão, eu me preparava legal, mas eu... sinto, eu... me sinto culpado, sei lá. É por isso que eu gosto de fazer alguma coisa pra não estar pensando". Sua primeira frase, sob impacto da surpresa, parece mais sincera; afinal, revela alguém que não se sente obrigado a estar constantemente preparado e à disposição de uma empresa, que pode chamá-lo ou não, angústia vivida por milhões de pessoas em todo o mundo e da qual Erasmo parece não compartilhar. Disse, em seguida, sentir culpa, sem nenhuma emoção, de uma forma mecânica, como quem repete o que alguém lhe disse que deveria sentir. Parece que a necessidade de trabalhar constantemente nos afazeres braçais da instituição está mais atrelada a evitar não ser cobrado para que procure emprego fora e ao discurso moral predominante na instituição do que a um desejo de voltar a um trabalho formal.

Apesar disso, deve-se ressaltar que o valor do trabalho como atividade que distingue os homens honestos e os vagabundos é bastante enfatizado na sua fala. Em dado momento da entrevista, afirma que era "meio alcoólatra", referindo-se a um período em que trabalhava. Aliás, parece que Erasmo só reconheceu verdadeiramente ter um problema com o álcool quando este o impediu de trabalhar.

No trecho de narrativa que segue, podemos entrever como o trabalho é utilizado para contrapor valores morais positivos e negativos:

Tem muitos aqui (na instituição) que se você falar em trabalhar chama a polícia ...Quem não tem vontade de trabalhar é só quem está no trecho que é fácil pedir, porque o dinheiro não está muito fácil não, mas a comida... Quando você está na rua e não tem (dinheiro) você se apavora, quando chega 18, 19 horas, principalmente quando tem que dormir de quebrada, dormir em qualquer lugar, tem que ter um trago (álcool).

Vida boa era quando eu morava com meus pais em São Miguel Paulista. Tem minha irmã Maria, que tem uma filha de 25 anos. Eu sou padrinho dela, eu sou padrinho de uns quatro. Eu era gente pra caramba! Agora eu sou gente, mas sou gente devagar, em vista do que eu era, porque essa minha sobrinha, ela tem até faculdade, e quando ela começou a estudar quem comprava, naquele tempo era bolsa, era caderno, caneta, quem comprava era tudo eu! Gostava muito!

"Eu era gente pra caramba!". Vê-se, aqui, que o trabalho que lhe conferia não só formas de subsistência, mas um lugar social, um lugar de provedor-autoridade na família, o status de humanidade, de relevância social. Quanto a filhos, diz que tem, mas nem os conhece, fruto de 
uma segunda viagem ao Rio de Janeiro, durante a qual permaneceu uns dois meses trabalhando como camelô, valendo-se de sua imagem para vender sandálias, de um modelo chamado de sandália da Wanderléia em alusão à cantora nacional que fez parte do movimento musical conhecido como "Jovem Guarda".

Observa-se, assim, que a narrativa de Erasmo indica que o trabalho o define como sujeito social, mas também mostra que ele tem um valor instrumental, no sentido de lhe proporcionar dinheiro, que associa à bebida e às mulheres.

\section{O novo trecheiro: liberdade e distanciamento}

Em contraposição à fala de Erasmo, que, aos 60 anos, contrabalança os momentos de aventura e liberdade nas ruas às privações e dores próprias dessa condição, ao mesmo tempo em que se compara aos irmãos que não dependem da assistência pública, vê-se Téo, um jovem trecheiro de 36 anos, entrevistado enquanto fazia malabares, vestido como um mímico, em um sinal de trânsito próximo a uma praça municipal.

Téo, trecheiro há sete anos, nascido no interior do Paraná, viajava, no momento da entrevista, com outros três jovens e, além das apresentações com malabares, produz artesanato e bijuterias com linhas coloridas trançadas. Téo prefere não ter sua voz gravada e propõe uma alternativa:

Tu tem papel aí? Faz assim, eu vou falando e tu anota tudo, pode anotar senão eu sei que depois vai ser foda pra tu lembrar. Depois eu dou uma olhada no que você escreveu e tudo bem.

Inicia sua narrativa falando dos anos de trabalho formal:

Já fui explorado sim. Já rendi muito dinheiro pros outros (...). Trabalhei quinze anos como garçom, virando noite. Não ganhava mal, mas também não ganhava o que merecia. Patrão é patrão, nunca vai pagar o certo, o que o trabalho do empregado vale, senão ele não tira o dele, né? Era legal, não era ruim não, eu não parava um instante, gente chamando, gente reclamando, gente pra servir. Virava a noite no bar e ainda fazia bico de evento. Formatura, casamento, essas coisas (...) Meus pais moram em L (sua cidade natal). Comecei trabalhando lá com 15 anos, mas depois mudei pra $\mathrm{C}$, meu último emprego foi lá. E você fica todo zuado (no trabalho de garçom à noite). Vai dormir de manhã e está claro, você já não dorme direito, fica o dia todo com o corpo zuado. Parece que tu nunca descansa, o sono não vale, não alivia.

Na fala de Téo, vê-se a consciência da divisão cortante entre patrão e empregado, relação percebida por ele como de exploração. Se na fala de Erasmo há uma intermitência entre o orgulho de ter desempenhado inúmeras funções, que lhe rendiam reconhecimento social e familiar, e o relato da vivência de um trabalho tedioso, vigiado, que não lhe possibilitava aprender coisas novas, Téo fala constantemente de seu sentimento de exploração e aprisionamento. Se Erasmo servia como apoio aos irmãos, Téo mantinha sua própria família, e sua ida às ruas deu-se devido ao esfacelamento desta:

Eu tinha minha esposa, mudei pra C. com ela, ficamos casados três anos, aí ela engravidou. Curti muito aquela barriga. Era tudo ótimo. A gravidez parecia que veio pra coroar nosso amor. Mas aí, no parto, ela morreu... Fiquei com a menina, eu paguei babá pra cuidar dela à noite, aquele tempo eu podia, trampava muito, mas até que ganhava legal, acho que dava hoje uns dois mi reais. Eu sozinho em C. com a Sol, minha filha chama Sol, a mãe desesperada em $\mathrm{L}$. Eu ralando à noite e de dia com a Sol no colo. Foi assim uns meses. Aí a mãe apareceu do nada em 
C. Cheguei em casa e a mãe e o pai estava lá. A mãe chorando porque tinha visto no jornal da televisão que babá batia nas crianças, que até tinha história de babá que roubava criança. A mãe chorando e veio pra levar a Sol pra ela cuidar, falou pra eu ir junto, voltar pra L. e morar com eles. Falei: "Não, faz assim: leva a Sol pra mãe não chorar e eu fico". A mãe levou a Sol e eu caí no mundo, ando sozinho. Conheço um monte de gente, em todo lugar tem conhecido, mas ando sozinho.

Sobre o vínculo com sua filha conta ele:

Não, não perdi contato com ela, não. A gente se fala quase todo dia, pelo menos toda semana por e-mail, e a Sol é esperta. Já tem o e-mail dela e escreve sozinha pra mim, meus irmãos mandam foto dela. Sei tudo dela. O medo da mãe é que ela seja que nem eu. Já coloque uma mochila nas costas e ganhe a BR. Uns dois meses atrás tive em L e perguntei se ela ia fazer como o pai e ela respondeu que agora não, que vai fazer os estudos primeiro antes de viajar (rindo, parecendo orgulhoso).

Interessante observar que, se Erasmo percebe a ida para o trecho como um processo gradativo, mas efetivo de ruptura com sua família e com o papel de provedor e autoridade que desempenhava nela, Téo não vê seu percurso atrelado a um distanciamento familiar. Erasmo tem filhos que não conhece, que não sabe onde estão, que não acompanhou e pelos quais não nutre nem afeto nem culpa. A não vinculação é clara, enquanto Téo tem uma filha que vê pouquíssimas vezes e que julga acompanhar de perto pelo mundo virtual.

Tomando-se essa imagem, de alguém que termina por se relacionar por meio da internet, é possível ainda interligar os sentimentos de Téo aos de Rico, que tem sua história narrada por Sennett (1999), em seu livro A corrosão do caráter. Rico é um rapaz vindo das classes populares que ascendeu às classes mais abastadas, apresentado por Sennett (1999) em comparação à história de seu pai, Enrico, faxineiro imigrante nos Estados Unidos. Dentre os inúmeros fatos apontados pelo autor, a fragilidade de contato social e familiar sentida por Rico parece aproximá-lo de Téo. Rico, em razão do tempo de dedicação ao trabalho, às características deste e às múltiplas mudanças de cidade e emprego realizadas ao longo de doze anos, comunica-se com seus filhos e amigos muito mais por e-mail e redes sociais do que pessoalmente.

O autor aponta o fenômeno de esgarçamento dos vínculos afetivos decorrente da não continuidade de tempo e lugar que caracteriza o trabalho flexível da atualidade. Nesse contexto, as redes de apoio de classe são enfraquecidas e perde-se a convivência que reforça os laços de solidariedade. Observa-se que esse contato primordialmente online com a família e amigos, que caracteriza a vida de Rico, também faz parte da vida de Téo. Mas, se tal estado de coisas é percebido por Rico como uma perda, se o contato online denuncia-lhe a distância dos filhos e faz com que tema pelos valores morais que venham a ter, no caso de Téo essa possibilidade de comunicação termina por escamotear o distanciamento das relações, impedindo-o de sentir que está perdendo o processo de crescimento da filha.

Perez (2001) lembra que, em tempos de globalização, muitos sujeitos são empurrados, pelas constantes mudanças econômicas, políticas e sociais, para uma movimentação constante. São frequentes as mudanças de trabalho, de casa ou amizades, o que obriga "um desenraizamento que exige grande mobilidade psicológica a fim de permitir uma rápida reorientação de identificações, comportamentos, sentimentos e relacionamentos" (p. 67). O autor afirma que essa constante reorientação reaquece movimentos de circularidade humana e, por isso, defende a necessidade de revisão da concepção tradicional de errância. Para ele, a movimentação constante não pode mais ser considerada como parte do rompimento com os códigos sociais, pois o atual momento histórico exigiria um tanto de errância de todos os 
sujeitos, por mais que continuem enredados em laços próprios ao mundo do trabalho e da família.

De acordo com o autor, "no mundo atual o imperativo do movimento não nos permite mais ficar parados em um só lugar; estamos constantemente em movimentação, mesmo que sentados defronte à tela de um computador, navegando na internet" (Perez, 2001, p. 68). Mais adiante, no mesmo artigo, afirma que, diante da mobilidade física e emocional que o atual momento histórico exige de todos, os trecheiros podem ser considerados como uma espécie de "caricatura" do homem pós-moderno.

Entretanto, considera-se, aqui, que, longe de ser uma caricatura, a vida nas ruas, mais precisamente no trecho, configura-se como uma possibilidade legítima de vivência humana. Diferentemente de Rico, que parece aprisionado pela "flexibilidade" do trabalho, que corrói o caráter (Sennett, 1999), a permanência no trecho pode ser vista como uma tentativa de viver fora dos padrões próprios ao mundo do trabalho formal, que se caracterizam pela busca constante de acumulação de bens e pela submissão a situações impostas pelo sistema. Essas afirmações podem ser vislumbradas na forma com que Téo afirma o valor de seu trabalho artesanal, que lhe confere autonomia e liberdade, e pela sua forte crítica à exploração dos patrões.

O discurso de Téo faz lembrar a cultura hippie, mas, diferentemente de Erasmo, que parece ter sido levado às ruas, fundamentalmente, por uma motivação hedonista, Téo apresenta um discurso politizado de recusa aos preceitos do sistema capitalista, ainda que não tenha em nenhum momento se referido diretamente a ele. Também fica claro que o que Téo busca não é o não trabalho. Em diversos momentos durante a entrevista, ele se afirma como "independente" e "trabalhador".

Téo também encara o uso de álcool e a dependência da assistência pública como marcas de inferioridade moral. Em suas palavras:

A gente fuma maconha. Maconha pra dar brisa. Mas não fico tomando álcool, não. (...) Ah, mas ai é fácil, encher a lata de cachaça e fazer cara de fracasso na frente da assistente social pra poder ganhar passagem. A gente não, não preciso disso. Eu trabalho, eu vendo meus trampos. Eu só vou aonde meu dinheiro dá pra ir. Só uma vez, em C., eu aceitei passagem, mas só porque a assistente social era muito gente fina, aí aceitei por causa dela.

No entanto, mesmo diante desse posicionamento, Téo não deixa de vivenciar grandes percalços no seu cotidiano na errância. A violência das ruas parece ser o principal. Diz ele:

.... a parte ruim é a polícia. Agora, esses dias mesmo em J. a gente apanhou. A polícia roubou tudo nossas linhas, as coisas, os materiais pra fazer nossos trampo e queriam duzentos reais pra liberar. Duzentos paus?! Nossa... A gente não faz esse dinheiro nem juntando os quatro junto! A gente faz uns cinquenta reais juntando tudo, duzentos reais não! Aí soubemos duma igreja que dava café da manhã e fomos lá. Chegamos lá, estavam os mesmos que bateram na gente falando que eram de um projeto que queria aproximar a polícia das pessoas em situação de rua. Eu não aguentei. Levantei meu braço e falei "que você quer aproximar se ontem à noite você deu com o cassetete na minha mão, pegou minhas coisas. Tá vendo esse machucado aqui na minha mão? Foi você, ontem!". A mulher ficou branca, ficou gaguejando com o microfone na mão, mas mesmo assim ainda tiraram umas fotos e, no dia seguinte, tinha nossa foto no jornal e embaixo escrito que eram os mendigos que participavam do projeto com a polícia (...) sem pedir nossa permissão, sem nada... Bem nossa cara no jornal... Mendigos... Eu sou trabalhador, não peço nada pra ninguém não. É só não me roubar que eu faço meus trampos!

Pode-se dizer, assim, que Téo afirma-se como trabalhador, mas não se dispõe a desempenhar qualquer trabalho. Afirma seu direito de trabalhar autonomamente e encara este 
como meio para manter seu caminhar. Quer trabalhar, mas rejeita o enquadre da relação empregador-patrão. Essa postura, no entanto, rende-lhe a desaprovação da família e, provavelmente, um maior distanciamento dela. Em um momento posterior da entrevista, relata a vergonha de sua mãe diante de sua atividade socialmente desqualificada:

\begin{abstract}
Quando estou em L., a mãe pede pra eu não fazer o que eu faço (malabares e venda de artesanato). Aí eu vou longe de casa, saio sem dizer que vou fazer e ela finge que não sabe. Se algum conhecido fala que me viu, ela diz que sente vergonha. Pra ela eu tinha que morar com eles e voltar a ser garçom. Ela não entende por que alguém que tem família dorme e trabalha na rua. Ela fala de como eu ia trabalhar bonito, de calça e camisa bem passada, mas ela não via que eu voltava fedendo a cigarro e gordura, tudo zuado. Mas mãe é mãe, tadinha. Ela chora. Só quer o que acha que é bom pra mim.
\end{abstract}

Nas palavras de Téo, o lugar de pertencimento social propiciado pelo trabalho como garçom seria o orgulho de sua mãe, mas não lhe interessa. Quer continuar na vida atual, que lhe faz sentir uma liberdade que o trabalho formal nunca lhe propiciou. Mas, seria Téo tão diferente de Erasmo?

\title{
Novos e velhos trecheiros: orgulho e humilhação
}

Téo não se envergonha de sua função, mas reconhece o direito da mãe em se preocupar com ele. Já Erasmo fala de sua vergonha ao desempenhar uma atividade socialmente desqualificada:

Eu tive carrinho de papelão também. No começo era difícil, dava uma vergonha, principalmente na "praça da música" (conhecida praça municipal), ali onde fica o ponto de ônibus, porque sempre tinha gente que me conhecia... Eu não passava pelo ponto do ônibus, eu dava a volta, de vergonha.

Sawaia (2002), ao defender a utilização dos afetos como categorias de análise, afirma como estes encerram no corpo o status de exclusão/inclusão social, relegando ao indivíduo incluído perversamente e ao seu corpo a personificação do que é socialmente desprezado. De acordo com ela, "a vergonha e a culpa são apresentadas como sentimentos morais generativos e ideologizados com a função de manter a ordem social excludente, de forma que a vergonha das pessoas e a exploração social constituem as duas faces de uma mesma questão” (p. 102).

A autora aponta ainda as emoções como construídas historicamente e em constante constituição. A vergonha seria uma emoção essencialmente social, pois é sentida tão somente a partir do temor do olhar de reprovação do outro, da dor de ser socialmente tratado com desprezo, indiferença, repúdio, escárnio. Finaliza ela apontando que a vergonha se inscreve de tal forma no corpo que é possível "morrer de vergonha" (Sawaia, 2002).

Nesse sentido, é interessante observar como a fala de Erasmo - que está há muito tempo nas ruas e já debilitado pelos desgastes impostos por essa vida - carrega um misto de orgulho por seu estilo de vida 'fora do sistema' e de vergonha por não ser como seus irmãos. Já Téo fala da vergonha da mãe pela sua opção de vida, mas ele mesmo não parece senti-la. Ao contrário, em algumas passagens da sua narrativa, frisa o orgulho de não se curvar à "exploração", o mesmo orgulho que parecia sentir Erasmo, quando jovem ao sair de um trabalho para "torrar" o salário em diversão. 
No entanto, ambos destacam a humilhação cotidiana pela condição de pobreza que a vida nas ruas lhes impõe, humilhação que se expressa de diversas formas, seja na violência da polícia, seja na reprovação do olhar do outro. A esse respeito Gonçalves Filho (1998) diz o seguinte:

\begin{abstract}
A humilhação é uma modalidade de angústia que se dispara a partir do enigma da desigualdade de classes. Angústia que os pobres conhecem bem e que, entre eles, inscrevese no núcleo de sua submissão. Os pobres sofrem frequentemente o impacto dos maus tratos. Psicologicamente, sofrem continuamente o impacto de uma mensagem estranha, misteriosa: "vocês são inferiores". E, o que é profundamente grave: a mensagem passa a ser esperada, mesmo nas circunstâncias em que, para nós outros, observadores externos, não pareceria razoável esperá-la. Para os pobres, a humilhação ou é uma realidade em ato ou é frequentemente sentida como uma realidade iminente, sempre a espreitar-lhes, onde quer que estejam, com quem quer que estejam (p. 53).
\end{abstract}

As formas de trabalho compatíveis com a vida nas ruas também são fonte de orgulho e de humilhação em ambos os casos, ainda que Téo expresse mais o primeiro sentimento e, Erasmo, o segundo. Nesse sentido, a contraposição entre as falas apresentadas pelos dois possibilita apontar a rua não como um espaço de fuga ao trabalho em si, nem como uma tentativa de viver da assistência do Estado, conforme o discurso social predominante, mas como um espaço legítimo de construção de formas de viver alternativos aos modos de organização formais. Conclui-se, assim, que tanto Erasmo como Téo mostram uma resistência ao lugar de submissão que lhes foi imposto pelos modos instituídos de trabalho. Por outro lado, vivenciam a insegurança, as incertezas e as humilhações a que estão fadados aqueles que vivem nas ruas.

Os aspectos das vidas desses trecheiros destacados aqui também possibilitam visualizar a ida para o "trecho" como um processo complexo, que envolve diferentes fatores, que vão muito além de um fato traumático, igualmente presente na concepção social hegemônica. Pode-se também dizer que Erasmo e Téo são dois exemplos de uma ampla categoria populacional que, apesar de materialmente próxima, guarda muitas diferenças quanto ao seu "estar nas ruas". Seja por aventura, por desespero, seja, ainda, como forma de continuar brigando pela subsistência, muitas pessoas vão às ruas realizar ampla gama de atividades, que têm em comum o fato de serem todas socialmente desqualificadas e motivo de sanções sociais e humilhação.

Enquanto Erasmo está debilitado pelo álcool, já não encontra trabalho com tanta facilidade e depende de um sistema de assistência pública que, por vezes, impõe a ele padrões de conduta, Téo se mantém em sua busca diária por liberdade e subsistência. Contudo, sem amparo e nenhum plano, pessoal e/ou público, que o apoie mais adiante, pode, futuramente, encontrar-se em situação similar àquela agora vivida por Erasmo.

Nesse contexto, diversos fatores - como a falta de garantia de condições de vida, de descanso, de cuidados mínimos com a saúde e a higiene, que permitam a esses indivíduos manter-se provedores de si; o viver centrado na resolução de necessidades imediatas possibilitado pelo trabalho que garante apenas a sobrevivência a cada dia; a falta de qualquer tipo de rede de seguridade que possa amparar os imprevistos e mesmo as dificuldades advindas do avançar da idade - terminam por fadar a população de rua aos cuidados de uma assistência paternalista que entra em cena somente quando as condições precárias, econômicas e/ou de saúde, tornam-se crônicas.

A título de suscitar novos questionamentos e outros estudos, vale informar que, antes do término da pesquisa que serviu de base para este artigo, Erasmo foi reencontrado nas ruas, sujo, barbudo, embriagado e com os pés feridos. Voltara ao trecho... 


\section{Referências}

Bastos, C. M., Toseli, C., Aquino Júnior, F. \& Bove, M. C. (2003). Pastoral do povo da rua. São Paulo: Loyola.

Bosi, E. (Org.). (1996). Simone Weil: a condição operária e outros estudos sobre a opressão (2 ${ }^{\underline{a}}$ ed. revista). São Paulo: Paz e Terra.

Decreto Sem Número de 25 de outubro de 2006 (2006, 25 de outubro). Política Para Inclusão Social da Pessoa em Situação de Rua. Diário Oficial da União.

Braverman, H. (1987). Trabalho e capital monopolista: a degradação do trabalho no século XX. Rio de Janeiro: Guanabara Koogan.

Bresciani, M. S. M. (1982). Londres e Paris no século XIX: o espetáculo da pobreza. São Paulo: Brasiliense.

Brognoli, F. F. (1996). Trecheiros e pardais: uma etnografia de nômades urbanos. Dissertação de Mestrado, Universidade Federal de Santa Catarina, Florianópolis.

Chizzotti, A. (2006). Pesquisa qualitativa em ciências humanas e sociais. Petrópolis: Vozes.

Da Matta, R. (1978). O ofício do etnólogo, ou como ter “anthropological blues”. In: R. Da Matta (Org.), A aventura antropológica. Rio de Janeiro: Zahar.

Frangella, S. M. (2004) Corpos urbanos errantes: uma etnografia da corporalidade de moradores de rua em São Paulo. Tese de Doutorado, Instituto de Filosofia e Ciências Humanas, Universidade Estadual de Campinas, Campinas.

Geertz, C. (1989). A interpretação das culturas. Rio de Janeiro: Guanabara.

Gonçalves Filho, J. M. (1998). Humilhação social: um problema político em psicologia. Psicologia USP, 9 (2), 11-67.

Hammersley, M. \& Atkinson, P. (1994). Etnografia: métodos de investigación. Barcelona: Paidós.

Himmelfarb, G. (1988). La idea de la pobreza. Inglaterra a princípios da la época industrial. Cidade do México: Fondo de Cultura Econômica.

Hobsbawm, E. J. (1982). A era das revoluções: 1789-1848. São Paulo: Paz e Terra.

Jacques, M. G. C. (1996). Identidade e trabalho: uma articulação indispensável. In M. G. C. Jacques \& A. Tamayo (Orgs.), Trabalho, organizações e cultura. Recuperado em 12 de maio de 2011 de www.infocien.org/Interface/Colet11.htm.

Paugam, S. (2003). Desqualificação social: ensaio sobre a nova pobreza. São Paulo: Educ.

Perez, R. S. (2001). Andarilhos de estrada: estudo das motivações e da vivência das injunções características da errância. Psico-USF, 6 (1), 67-75.

Santos, M. S. (2004). A prisão dos ébrios, capoeiras e vagabundos no início da Era Republicana. Revista Topoi, 5 (8), 138-169.

Sawaia, B. B. (2002). Introdução: exclusão ou inclusão perversa? In B. B. Sawaia (Org.), As artimanhas da exclusão: análise psicossocial e ética da desigualdade social (pp. 7-13). Petrópolis: Vozes.

Seligmann-Silva, E. (1994). Desgaste mental no trabalho. São Paulo: Cortez.

Sennett, R. (1999). A corrosão do caráter. Rio de Janeiro: Record.

\section{Endereço para correspondência}

sanbpsico@hotmail.com,marciahb@puc-campinas.edu.br 